\title{
OPTIMIZATION AND KINETIC STUDY OF ANTHRAQUINONE DYE REMOVAL FROM COLORED WASTEWATER USING SOYBEAN SEED AS A SOURCE OF PEROXIDASE
}

\author{
Milica Svetozarević ${ }^{1, *}$, Nataša Šekuljica ${ }^{1}$, Zorica Knežević-Jugović ${ }^{2}$, Dušan Mijin ${ }^{2}$ \\ ${ }^{1}$ Innovation Center of the Faculty of Technology and Metallurgy, Karnegijeva 4, 11000 Belgrade, Serbia \\ ${ }^{2}$ University of Belgrade, Faculty of Technology and Metallurgy, Karnegijeva 4, 11000 Belgrade, Serbia
}

msvetozarevic@tmf.bg.ac.rs

\begin{abstract}
As water contamination emerges as a serious threat to the environment, ventures for cleaner and sustainable solutions are continuously being developed. The present study investigates the ability of crude peroxidase extract from soybean seeds to degrade the anthraquinone dye Acid Violet 109. The influence of the essential parameters $\mathrm{pH}$, dye concentration, hydrogen peroxide dosage, and temperature were inspected. The enzyme had $81.9 \%$ biodegradation at $\mathrm{pH} 4$ in 30 min with $0.1 \mathrm{U}$ peroxidase, $40 \mathrm{mg} / \mathrm{l}$ dye concentration, and $1 \mathrm{mM}$ hydrogen peroxide. Considering that substrate concentration can cause reaction inhibition, a kinetic study was performed. Kinetic data fitting using bisubstrate kinetics with a substrate inhibition model revealed the high inhibitory effect of the dye, which was confirmed by the inhibition constant, $7.123 \cdot 10^{-5} \mathrm{mM}$. Alongside the inhibition constant values, the Ping-Pong Bi-Bi model gave the maximum rates 15.788 and $14.321 \mathrm{mM} / \mathrm{min}$ for hydrogen peroxide and dye inhibition, respectively.
\end{abstract}

Keywords: soybean seed peroxidase; acid violet 109; Ping-Pong Bi-Bi; dye treatment

\section{СТУДИЈА ЗА ОПТИМИЗИРАЬЕ И КИНЕТИКА НА ОТСТРАНУВАЊЕ АНТРАХИНОНСКА БОЈА ОД ОБОЕНА ОТПАДНА ВОДА СО КОРИСТЕЊЕ СОЈА КАКО ИЗВОР НА ПЕРОКСИДАЗА}

\begin{abstract}
Загадувањето на водата претставува сериозна закана за животната средина. Затоа секојдневно се развиваат одржливи решенија. Во оваа студија е истражувана способноста на суровиот екстракт од соја кој содржи пероксидаза да ја разгради антрахинонската боја Acid Violet 109. Исто така е испитувано влијанието на параметрите $\mathrm{pH}$, концентрација на боја, водороден пероксид и температура врз процесот на разградување. Ензимот покажа 81,88 \% биоразградување на $\mathrm{pH} 4$, за 30 минути со пероксидаза $0,1 \mathrm{U}$, при концентрација на боја $40 \mathrm{mg} / \mathrm{l}$ и присутен $1 \mathrm{mM}$ водороден пероксид во супстратот. Со оглед на тоа дека концентрацијата на супстратот може да биде инхибиторна за ензимот, испитани се и кинетичките параметри. Со фитување на кинетичките податоци, користејќи го моделот за бисупстратна кинетика со супстратна инхибиција, дојдено е до заклучок дека концентрацијата на бојата има голем инхибиторен ефект, што е потврдено со константа на инхибиција од $7,123 \cdot 10^{-5} \mathrm{mM}$. Освен вредностите на константите на инхибиција, преку моделот Пинг-Понг Би-Би се добиени максимални брзини на инхибиција за водороден пероксид и боја, кои изнесуваат 15,788 и $14,321 \mathrm{mM} / \mathrm{min}$, соодветно.
\end{abstract}

Клучни зборови: пероксидаза од coja; acid violet 109; Пинг-Понг Би-Би; третман на бои

\section{INTRODUCTION}

Almost one-third of the planet's inhabitants cope with severe water depletion for 4-6 months annually. The most affected regions are highly populated areas, agronomic zones that require irrigation, or places where water attainability is poor. The levels of water in rivers, lakes and even groundwater decrease, leading to reduced harvest, land collapse, salinization of soils, and impairment of flora and fauna [1-4]. Moreover, all production and supply sites, where water is essential, carry a 
great risk of water scarcity. A potential reason behind the water depletion is a lack of protection of the ecosystems where the water is from or insufficient sustainable solutions for water decontamination from industrial pollutants. Specific types of pollutants, that have been raising questions ever since they emerged as an issue, are dyes used in the textile industry. These dyes represent a constant challenge with a variety of offered solutions, which leaves space for the development of new methods. Dye concentrations in colored effluents range between 10-200 $\mathrm{mg} / \mathrm{l}$, which is more than enough to cause a pH imbalance, eutrophication, decrease oxygen, and interfere with light refraction in water [5]. Moreover, it can affect human health, as these pollutants are related to respiratory problems, toxicity and carcinogenicity [6]. Next to azo dyes, which make up $70 \%$ of the textile dyeing market [7], anthraquinone dyes pose a threat due to their fused aromatic rings, making their degradation more complex [8]. For this purpose, a variety of physical, chemical and combined methods have been developed. Activated carbon is widely used for dye removal due to its remarkable properties such as mechanical and chemical stability as well as its high surface-to-volume ratio. Bamboo, pinewood, sugarcane bagasse and coconut shells are only a few precursors used for the preparation of activated carbon [9-13]. Porous silica nanoparticles have also shown a potential for the adsorption of different dyes [14]. Natural polymers such as tannins, pectins, alginates and gums as well as graft polymers are replacing the inorganic polymers (alum, $\mathrm{FeSO}_{4}$ ) since their key benefits are low toxicity, biodegradability, and reduced sludge formation [15-17].

Advanced oxidation processes, including ozone and Fenton treatments, are some of the most efficient methods of dye removal - up to $99 \%$. Still, the short lifetime of radicals, the low solubility of ozone in water, and energy costs represent serious obstructions for scaling-up [18-20]. Their overall cost, time consumption, lack of harmonization for different textile effluents, and formation of other toxic by-products launched alternative, biological methods: microbial and enzymatic. Bacillus sp., Pseudomonas, Shewanella sp., Aeromonas and Klebsiella sp. are successfully used for anthraquinone dye degradation [21-25]. Enzyme treatments prevail over the microbial ones because of their ability to withstand the dye's high concentration, which is lethal to microorganisms. Furthermore, when microorganisms are used, there is a lagging period needed for microorganisms to adapt. With enzymes, this period is avoided, as is sludge formation. It is important to note that enzymes tolerate a wider range of $\mathrm{pH}$ values and tempe- ratures, and are easier to manipulate. Enzymes are replacing other technologies because they represent green solutions for wastewater treatment, and they can be easily applied and adjusted, as well as that they do not require state-of-the-art equipment for operation. This allows innovation development and staying up to date with the latest findings at low costs [26]. The trending enzyme used for dye degradation is peroxidase due to its potential for pollutant removal from effluents. Horseradish peroxidase has found its way to the top as an effective tool for dye degradation [27-31]. Other plant sources such as potatoes, cabbage and bananas have also been investigated for peroxidase extraction and showed good results [32-34]. Among them, soybean is one of the most promising plant sources of peroxidase since it is a readily available and cost-effective source with outstanding properties. The characteristic of soybean peroxidase that stands out in comparison with other peroxidases is its remarkable temperature stability at temperatures up to $70{ }^{\circ} \mathrm{C}$ [35-38].

In this study, soybean peroxidase is used for the degradation of a specific pollutant present in wastewater - anthraquinone dye Acid Violet 109 (AV109). AV109 dye belongs to synthetic sulfonated anthraquinones that are very important starting materials for the production of a large palette of dyes. This dye has an organosulfonate group bearing an important role, not only in altering the solubility and dispersion properties of the dye molecule but also in increasing recalcitrance to microbial breakdown because of the thermodynamically stable carbon-sulfur bond. Due to this structure, the microorganisms have a poor capability to degrade sulfono-aromatic compounds, i.e. they are ineffective in managing this significant class of contaminant in dyeing wastewaters. Therefore, green plant-based treatments are being explored and they include the use of different agroindustrial residues. A crude enzyme extract is used to simplify the method and shorten the overall process. According to our knowledge, the available literature of soybean peroxidase deals with azo dyes removal and benzidines [39-41], but not with anthraquinone dye degradation.

For the optimization of the biodegradation, the effects of several parameters were investigated: $\mathrm{pH}$, dye concentration, enzyme concentration, hydrogen peroxide dosage, and temperature. Since the substrate concentration can affect the biodegradation in a great manner, additional experiments were conducted for obtaining the kinetic data of the enzymes and later modeling them according to the mechanism of bisubstrate reactions. 


\section{MATERIALS AND METHODS}

\subsection{Materials and reagents}

C.I. Acid Violet 109 was obtained from Lanaset (USA); Soybean (Glycine max) was purchased from Sojaprotein (Serbia). The rest of the chemicals were analytical reagent grade commercial products.

\subsection{Preparation of soybean peroxidase crude extract}

Distilled water was added to the soybean seeds in a 1:4 ratio, followed by homogenization and incubation for $24 \mathrm{~h}$ at $4{ }^{\circ} \mathrm{C}$. The mixture was then filtered through gauze, and the filtrate was heated at $65{ }^{\circ} \mathrm{C}$ for $3 \mathrm{~min}$, to inactivate the catalase. Thereafter, immediate ice cooling was performed. The cooled extract was centrifuged for $15 \mathrm{~min}$ at $10^{4} \mathrm{rpm}$ (Heraeus ${ }^{\mathrm{TM}}$ Fresco $^{\mathrm{TM}} 17$ Microcentrifuge, Thermo Scientific, Waltham, USA). Before the supernatant was frozen, the enzyme activity was measured according to the standard procedure given in 2.3 [31].

\subsection{Enzyme activity assay}

Enzymatic activity was determined by using pyrogallol as a substrate in the presence of hydrogen peroxide [31]. Peroxidase catalyzes the oxidation of pyrogallol to purpurogaline, which is a brownish product. The $\mathrm{H}_{2} \mathrm{O}_{2}$ acts as an electron acceptor making it essential for the reaction. The activity was determined using a spectrophoto- metric analysis at $420 \mathrm{~nm}$. The reaction mixture contained $0.013 \mathrm{M}$ pyrogallol in a phosphate buffer solution $(\mathrm{pH} 7,0.1 \mathrm{M}), 10 \mu 13 \% v / v$ hydrogen peroxide and $10 \mu \mathrm{l}$ of enzyme solution. The change in absorbance (UV/Vis Ultrospec 3300 Pro, Amersham Bioscience, UK) was monitored at intervals of $30 \mathrm{~s}$ for $3 \mathrm{~min}$. One unit of activity is defined as the amount of peroxidase that will form $1 \mathrm{mg}$ of purpurogallin from pyrogallol in $20 \mathrm{~s}$ at pH 7.0 and $20^{\circ} \mathrm{C}$.

\subsection{Dye biodegradation parameters evaluation}

The biodegradation of the dye was performed by a crude peroxidase extract in a $100 \mathrm{ml}$ beaker with a magnetic stirrer at $150 \mathrm{rpm}$. Parameters of significance that drive the biodegradation rate are $\mathrm{pH}$, dye concentration, enzyme concentration, hydrogen peroxide dosage and temperature. To determine the $\mathrm{pH}$ of the reaction where the biodegradation is at the highest level, enzymatic reactions were monitored in dye solutions with different $\mathrm{pH}$ ranging 3-9. Citrate buffer was used for $\mathrm{pH} 3.0$, acetate buffer was used for $\mathrm{pH} 4-5$,

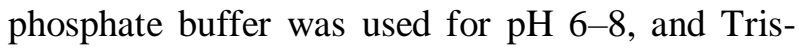
buffer was used for $\mathrm{pH} 9$, and all buffers had a concentration of $50 \mathrm{mM}$. The effect of dye concentration on the biodegradation was investigated by varying the dye concentration from 10$100 \mathrm{mg} / \mathrm{l}$. As for the hydrogen peroxide influence determination, its concentration was varied from 0.1 to $1 \mathrm{mM}$.

Table 1

Chemical structure of AV109 dye

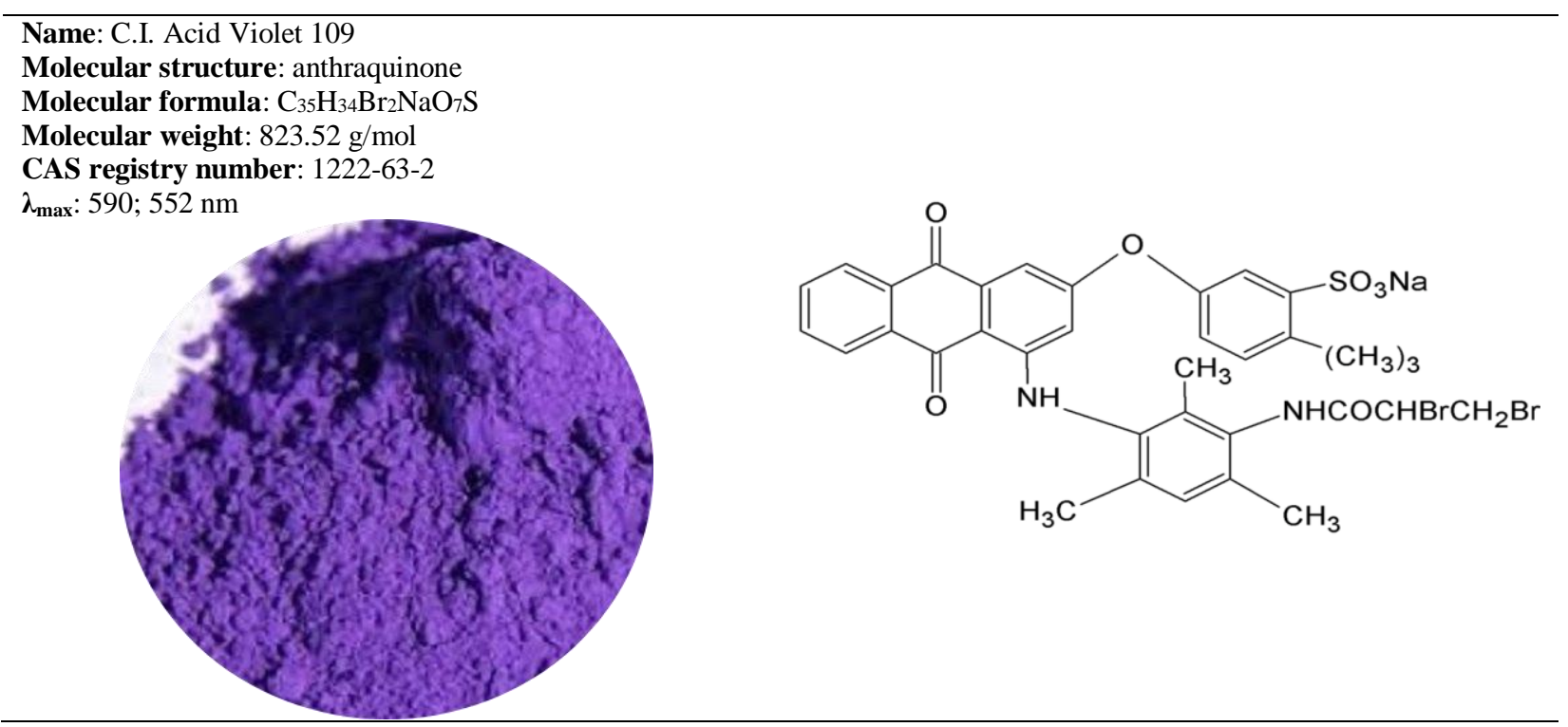


The biodegradation rate was inspected in terms of thermal influence at temperatures: 25,38 and $50{ }^{\circ} \mathrm{C}$, by incubating the reaction mixture in a water bath (Memmert, Schwabach, Germany). The biodegradation level was calculated using eq. 1:

$$
\text { BIODEGRADATION }(\%)=\left(\frac{A_{0}-A_{t}}{A_{0}}\right) \cdot 100,
$$

where $A_{0}$ is the initial absorbance of the reaction mixture, and $A_{\mathrm{t}}$ is the final absorbance at $590 \mathrm{~nm}$. AV109 dye was chosen as a model anthraquinone dye, and its chemical structure is given in Table 1.

\subsection{Kinetic study of AV109 dye biodegradation}

Since hydrogen peroxide, representing a cosubstrate for peroxidases, as well as the dye, can act as an inhibitor when present in excess concentrations, kinetic parameters are of crucial importance. For that purpose, the initial rates of dye biodegradation were assessed by varying the substrates' concentrations: firstly, the AV109 concentration, and in the next set of experiments the hydrogen peroxide concentration at $25{ }^{\circ} \mathrm{C}$ in 50 $\mathrm{mM}$ citrate buffer, $\mathrm{pH}$ 4.0. The initial rates were calculated, and together with the initial concentration of the substrates plotted using a mathematical model of bisubstrate reaction in OriginPro 8.5 program.

\subsection{Statistical analysis}

The experimental results included three replications. The results are presented as mean \pm standard deviation. Statistical differences were determined by one-way analysis of variance (ANOVA). A Tukey test was applied as a test of posterior probability with a level of significance of 95\%. All the tests were considered statistically significant at $p<0.05$. Statistical analyses including calculations were performed using Origin Pro 9.0 software package (Origin Lab Corp., Mass. USA).

\section{RESULTS AND DISCUSSION}

\subsection{Dye biodegradation parameters evaluation}

Initially, an enzyme was prepared to optimize the process parameters of AV109 dye degradation. The enzyme was extracted using a low-cost extraction procedure from soybeans according to the procedure previously described, and peroxidase activity in the crude extract was determined [35]. A low-cost extraction of crude peroxidase from soybean seeds was performed, followed by an activity assay. The enzyme showed an activity of $25 \mathrm{IU} / \mathrm{ml}$. Alyas et al. [42] extracted peroxidase from soybean seeds with the activity of the crude enzyme of $17.29 \mathrm{U} / \mathrm{ml}$. Their crude extract was subjected to several steps of purification where no significant increase of enzyme activity was noted, proving that enzyme purification, in this case, would not be justified. Rathnamsamy et al. [43] extracted peroxidase from different plant sources such as tomato, cabbage, turnip and radish. The activity of the crude enzyme extract varied from 1.1 to $1.7 \mathrm{IU} / \mathrm{ml}$, which is much lower than the activity of soybean crude extract in the current study. The extraction conditions such as reaction time, temperature, and $\mathrm{pH}$ may affect the enzyme concentration to the nature of the material for extraction. The assessment of the optimal $\mathrm{pH}$ is of great importance due to probable electrical charge alteration of the dye, which is dependent on the $\mathrm{pH}$ [44]. Apart from this, every enzyme requires a specific $\mathrm{pH}$ to exhibit its activity. The $\mathrm{pH}$ of the reaction is governed by the dye itself and by amino acid residues in the active site of the enzyme. These are the key factors that dictate the environment of the reaction in terms of $\mathrm{pH}$. In Figure 1, the influence of $\mathrm{pH}$ on the biodegradation rate of AV109 is given. The results indicate that soybean peroxidase has a wider $\mathrm{pH}$ optimum range, more precisely, and the approximate capacities for biodegradation were observed at pH $3(37.82 \%)$ and $4(51.35 \%)$.

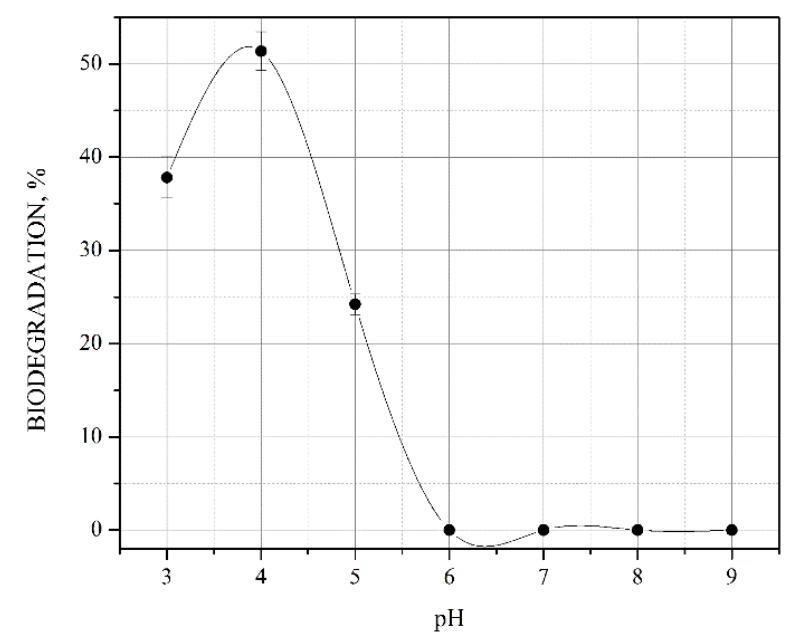

Fig. 1. The influence of the initial $\mathrm{pH}$ on AV109 biodegradation at room temperature by soybean peroxidase (reaction conditions: dye concentration $30 \mathrm{mg} / \mathrm{l}, \mathrm{H}_{2} \mathrm{O}_{2}$ concentration 0.1 $\mathrm{mM}$, enzyme concentration $0.1 \mathrm{U}$ ). Each data point represents the average value of three independent experiments. 
The acidic environment ( $\mathrm{pH} 3-4)$ satisfies the ionization states of both catalytic residues in soybean peroxidase, distal histidine (His 42 - catalytic base), and arginine ( $\operatorname{Arg}_{38}$ - charge stabilizer) [45]. When Šekuljica et al. used horseradish peroxidase and the same dye, the optimal $\mathrm{pH}$ was 4 [46]. The horseradish peroxidase showed no activity at all at $\mathrm{pH}$ 3. It is known that extremely acidic conditions can cause the release of iron from the porphyrin peroxidase ring. In our case, the soybean peroxidase retained its activity at $\mathrm{pH} 3$, which is a rare case when peroxidase is used. The soybean peroxidase is obviously suitable for reactions that occur at a quite low $\mathrm{pH}$. Besides, the removal efficiency fell off sharply at $\mathrm{pH}>6.0$, presumably due to hydrogen peroxide decomposition to water and oxygen under those conditions [45].

At the same time, the reaction duration was monitored. The reaction time is reflected in the retention time necessary for the removal of pollutants from the water. This parameter is decisive since it governs the reactor volume and the amount of capital investment in the entire process. After 30 min of contact, there was no noteworthy change in the biodegradation rate, thus the biodegradation in further experiments was monitored for $30 \mathrm{~min}$.

\subsection{Influence of the dye concentration and hydrogen peroxide on the biodegradation rate}

The substrate concentration in every enzyme-catalyzed reaction is a critical parameter whereas optimization is of crucial importance. The literature is rich in data on the influence of the initial concentration of dye on the degree of removal of synthetic dyes, and the scope of examination varies greatly. For instance, soybean peroxidase was used in the study of sulfonated dye cleavage performed by Kaur et al., in which, under the initial dye concentration (methyl orange) of $0.16 \mathrm{~g} / \mathrm{l}$ soybean peroxidase exhibited maximum conversion of $98 \%$ [45]. Furthermore, the crude soybean peroxidase extract was examined in methyl orange dye removal where the initial dye concentration was varied from 10 to $70 \mathrm{mg} / \mathrm{l}$. These literature findings coincide completely with the experimental range in this study, where the initial dye concentration was varied in the range of 10 to $100 \mathrm{~g} / \mathrm{l}$ (Fig. 2). The highest biodegradation rate of $66.81 \%$ was achieved when the dye concentration was 40 $\mathrm{mg} / \mathrm{l}$. At higher dye concentrations, an immediate drop in the degradation rate was noticed. At a concentration of $100 \mathrm{mg} / \mathrm{l}$, the biodegradation rate was $21 \%$, indicating that a possible inhibition is present (Fig. 2a). Mandujano et al. used soybean peroxidase for degradation of an azo dye at $\mathrm{pH} 5,40$ ${ }^{\circ} \mathrm{C}, 40 \mathrm{mg} / \mathrm{l}$ dye concentration, and $15 \mathrm{U} / \mathrm{ml}$ enzyme activity [47]. They reached $70 \%$ of biodegradation. Given the fact that due to the carbonyl groups of the anthracene core and resonance effects within its structure, the anthraquinone dyes are more difficult for degradation than the azo ones [48]. Nevertheless, the peroxidase showed satisfying results which suggest that it is suitable for the degradation of anthraquinone dyes. a)

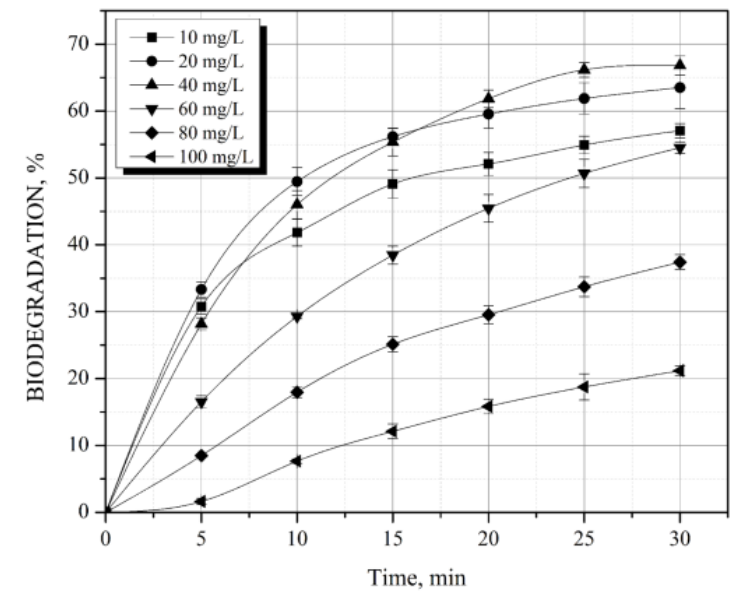

b)

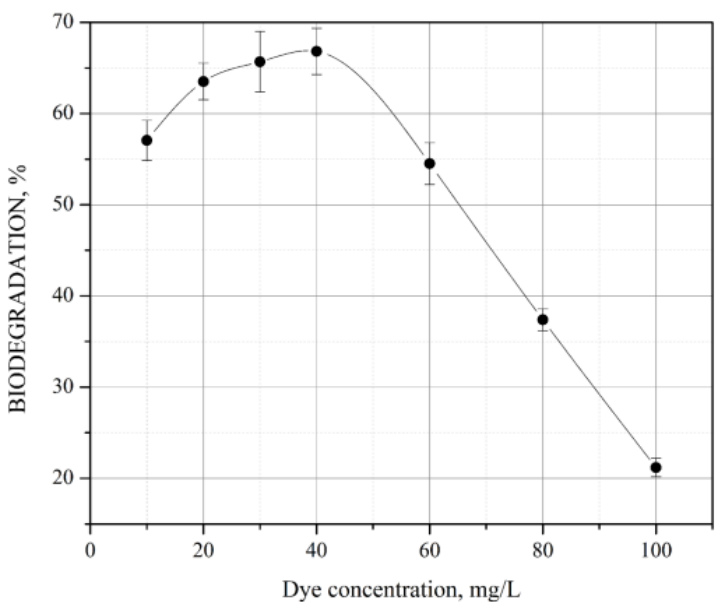

Fig. 2. The effect of the dye concentration on the dye removal catalyzed by soybean peroxidase, a) the influence of dye concentration on the biodegradation rate as a function of time. b) the biodegradation rate as a function of the dye concentration (reaction conditions: temperature $25^{\circ} \mathrm{C}, \mathrm{pH} 4$; contact time $30 \mathrm{~min}$, enzyme concentration $0.1 \mathrm{U}$, hydrogen peroxide concentration $0.1 \mathrm{mM}$ ). 
The effect of hydrogen peroxide dosage on dye biodegradation is given in Figure 3. It is often alleged that excess hydrogen peroxide concentrations can have an inhibitory effect and thus lower the dye biodegradation. However, the results show that a higher concentration of hydrogen peroxide did not have a considerable impact on the reaction rate. On the contrary, a low hydrogen peroxide dosage led to the decreased efficiency of the enzyme. With $0.01 \mathrm{mM}$ hydrogen peroxide, only $28 \%$ biodegradation was achieved, while the highest decolorization rate of $77.5 \%$ was observed with $1 \mathrm{mM}$ hydrogen peroxide. Actually, it is the insufficient concentration of hydrogen peroxide that limits the reaction. Silva et al. [49] came to a similar conclusion on the example of Remazol brilliant blue $\mathrm{R}$ decolorization by soybean peroxidase at $\mathrm{pH} 6,30{ }^{\circ} \mathrm{C}, 40 \mathrm{mg} / \mathrm{l}$ dye concentration, and $70.4 \mathrm{U} / \mathrm{ml}$ enzyme activity.

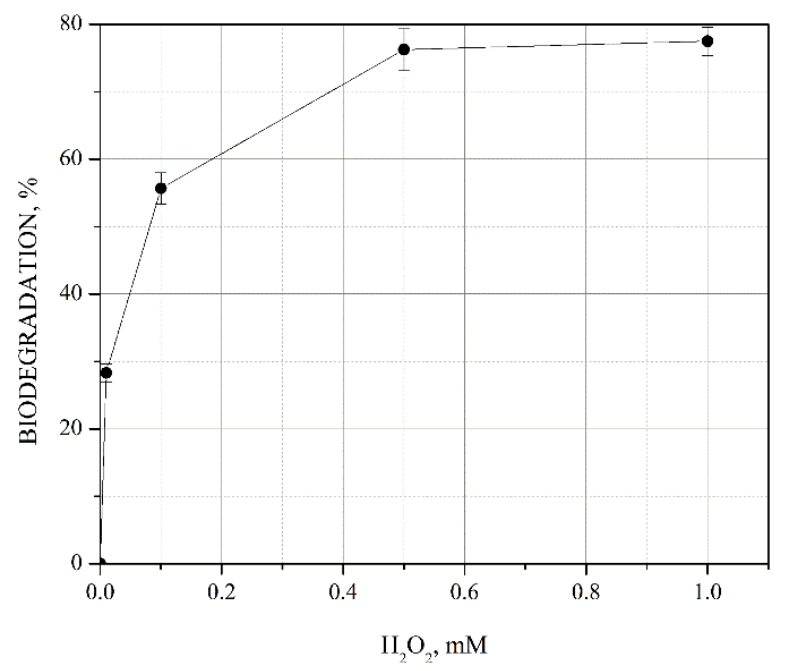

Fig. 3. The effect of hydrogen peroxide dosage on dye removal catalyzed by soybean peroxidase (reaction conditions: temperature $25^{\circ} \mathrm{C}, \mathrm{pH} 4$; contact time $30 \mathrm{~min}$, enzyme concentration $0.1 \mathrm{U}$, dye concentration $40 \mathrm{mg} / \mathrm{l})$. Each data point represents the average value of three independent experiments.

The $\left[\mathrm{H}_{2} \mathrm{O}_{2}, \mathrm{mM}\right]:[\mathrm{AV} 109, \mathrm{mM}]$ ratio in this study differs significantly from the predicted theoretical values based on the mechanism of oxidoreductase action. Hydrogen peroxide is a stoichiometric co-substrate that can be an activator but also an inhibitor in excessive amounts. In theory, the stoichiometric coefficient for hydrogen peroxide is 0.5 ; however, this value differs significantly. In this study, it was noted that the maximum efficiency of soybean peroxidase was recorded at a $\left[\mathrm{H}_{2} \mathrm{O}_{2}, \mathrm{mM}\right]:[\mathrm{AV} 109, \mathrm{mM}]=20$. Although quite different from the predicted theoretical value, such results are common in the literature. Namely, the degradation of different classes of dyes catalyzed by soybean peroxidase: Acid Blue 113, Crystal Ponceau 6R and Direct Black 38, was achieved under $\left[\mathrm{H}_{2} \mathrm{O}_{2}, \mathrm{mM}\right]:$ [substrate, $\mathrm{mM}]$ ratios of [2.5] : [1.0], [0.175]: [0.059] and [2.5] : [0.5], respectively $[41,50]$. The results of our study regarding the $\left[\mathrm{H}_{2} \mathrm{O}_{2}, \mathrm{mM}\right]:[\mathrm{AV} 109, \mathrm{mM}]$ ratio agree best with the study performed by Chiong et al. where the degradation of methyl orange dye catalyzed by soybean peroxidase (fresh extract) was monitored [51]. In this study, $\left[\mathrm{H}_{2} \mathrm{O}_{2}, \mathrm{mM}\right]$ : $[\mathrm{AV} 109, \mathrm{mM}]=22$ was confirmed, which agrees very well with the presented results. The need for a larger amount of hydrogen peroxide than the theoretical value is attributed to the presence of additional enzymes that can be found in the mixture, especially if it is a crude extract in question that will have an affinity for hydrogen peroxide. For example, the presence of ascorbate peroxidase and catalase, hydrogen peroxide-scavenging enzymes, has been confirmed in soybean plant tissue [51].

In addition, during the reaction, no precipitate formation was observed, which could be explained by the fact that oligomers of reduced solubility are not assembled, but mainly oligomers that are well soluble under given conditions [45]. Accordingly, the increase in co-substrate content in the reaction is often attributed to parallel degradation cycles where the oligomers formed in one phase re-enter the enzyme cycle and are degraded, thus an additional amount of co-substrate is required for the incoming substrate molecule, dye.

\subsection{Effect of temperature on AV109 biodegradation}

As a corollary to the overall dyeing operations, the resulting wastewater leaves the process at high temperatures, so an enzyme with good stability and activity at a wide range of temperatures is preferable. Thusly, the peroxidase treatment efficiency of the dye solution was investigated at temperatures: 25,38 and $50{ }^{\circ} \mathrm{C}$. Figure 4 shows the influence of temperature at $\mathrm{pH} 4,40$ $\mathrm{mg} / \mathrm{l}$ dye concentration, and $0.1 \mathrm{U}$ enzyme concentration on biodegradation. At $60{ }^{\circ} \mathrm{C}$, the soybean peroxidase did not show any activity, which is expected since it is generally recognized as a heat-stable enzyme that retains its activity even at $70{ }^{\circ} \mathrm{C}$ [38]. Nevertheless, there are also exceptions, where the optimal temperature of soybean peroxidase is $30{ }^{\circ} \mathrm{C}$ [52]. The optimal temperature of the AV109 biodegradation by soybean peroxidase was $38{ }^{\circ} \mathrm{C}$, when $81.88 \%$ decolorization was achieved, Figure 4. 


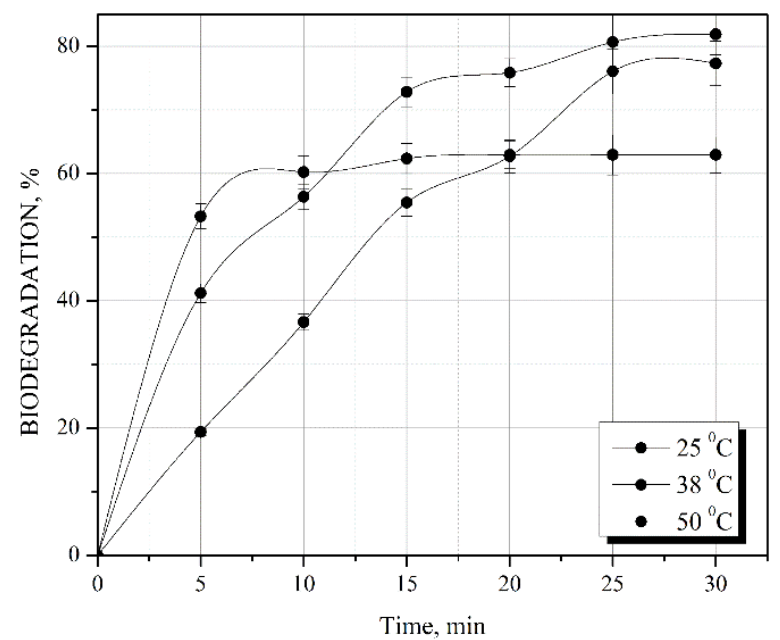

Fig. 4. The influence of temperature on the AV109 biodegradation catalyzed by peroxidase from soybean (reaction conditions: $\mathrm{pH} 4$; contact time: 30 min; enzyme concentration: $0.1 \mathrm{U} ; 1 \mathrm{mM} \mathrm{H}_{2} \mathrm{O}_{2} ; 40 \mathrm{mg} / \mathrm{l}$ dye concentration)

\subsection{Enzyme kinetics}

Longu et al. investigated the horseradish peroxidase mechanism of action [53]. They stated the formation of an intermediate compound (EI) acquired from the process of oxidation which occurs when the peroxide binds to the enzyme's heme- $\mathrm{Fe}^{3+}$. Thereafter, EI is reduced by the substrate (dye), and compound EII is formed. EII compound is again reduced with another substrate molecule, where the enzyme returns to its native form. Production of a dead-end complex is possible if the reaction conditions are not optimized. This can be identified as a bisubstrate
Ping-Pong $\mathrm{Bi}-\mathrm{Bi}$ reaction, as it is confirmed by Šekuljica et al. [46]. Thus, the initial kinetic experimental data for the biodegradation by soybean peroxidase were studied according to the Ping-Pong Bi-Bi model [46].

For the kinetic study, the dye concentration was varied while the other parameters were fixed at their optimal values. The next experiment was conducted by varying the hydrogen peroxide concentration. From Figure 5a it can be concluded that the hydrogen peroxide concentration had a positive impact on the biodegradation of AV109. This was confirmed by fitting the data with the model without inhibition $\left(R^{2}=0.9981\right)$. The similar experimental data were additionally fitted with a kinetic model with hydrogen peroxide inhibition (Fig. 5(a), red line).

It is evident that the assumed mathematical model with hydrogen peroxide inhibition is less suitable, which confirms the value $R^{2}=0.96034$. When the Michaelis constant derived from horseradish [46], is compared with the abovestated results, it can be concluded that the soybean seed peroxidase has a higher affinity towards hydrogen peroxide $(0.2356 \mathrm{mM}$ for horseradish peroxidase and $0.1091 \mathrm{mM}$ soybean seed peroxidase). As for the dye, it can be clearly seen that it has an inhibitory effect and leads to the formation of a dead-end complex. If it is compared with the results of the kinetic study for horseradish peroxidase by Šekuljica et al. [46], the soybean peroxidase has a higher affinity towards the dye than the horseradish peroxidase. a)

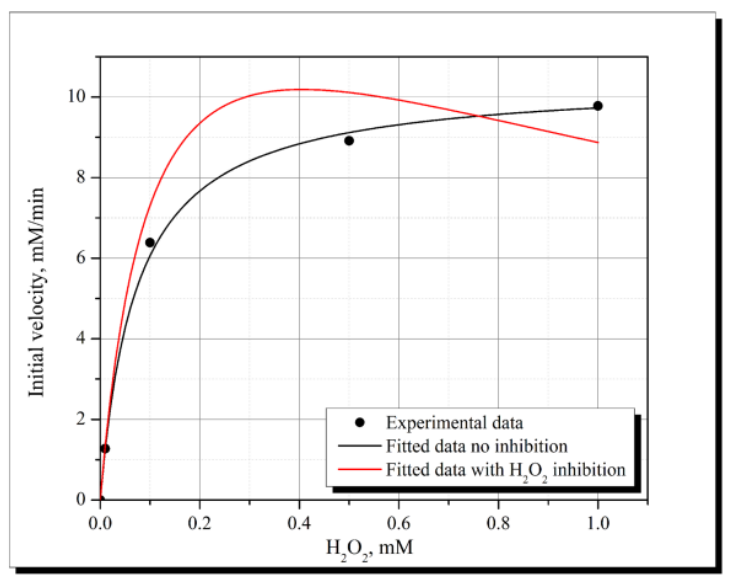

b)

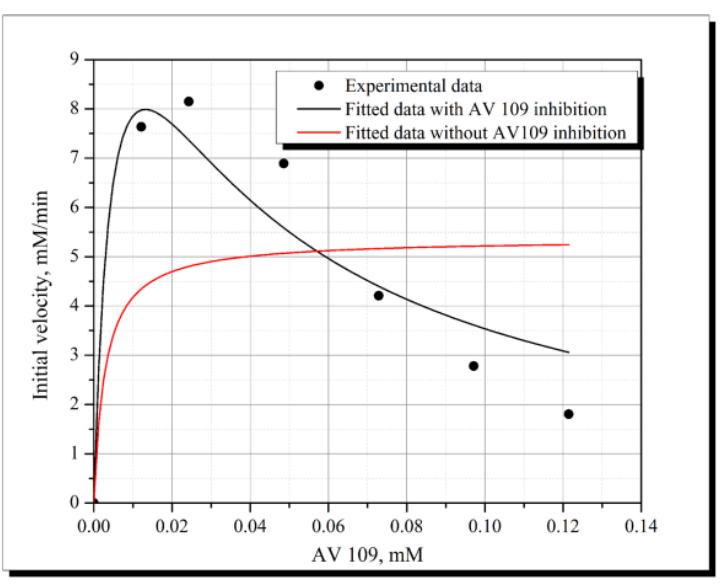

Fig. 5. a) The influence of the initial hydrogen peroxide concentration on the initial rate of the reaction under the constant dye concentration of $0.048 \mathrm{mM}$. The curve is fitted according to the experimental data and the kinetic model that excludes hydrogen peroxide inhibition (kinetic model with hydrogen peroxide inhibition — red line); b) The influence of the initial dye concentration on the initial rate of the reaction under the constant hydrogen peroxide concentration, $1 \mathrm{mM}$. The curve is fitted according to the experimental data and the kinetic model for inhibition with the dye (kinetic model without dye inhibition — red line). 
Namely, the Michaelis constants obtained from the mathematical model for the dye for soybean peroxidase and horseradish peroxidase are 0.0052 $\mathrm{mM}$ and $0.2374 \mathrm{mM}$, respectively. Furthermore, the tested dye has a higher inhibitory effect on soybean peroxidase rather than horseradish peroxidase. To further support the evidence of the higher inhibitory effect of soybean peroxidase by the dye, the $K_{\mathrm{i}}$ values are compared: $7.1234 \cdot 10^{-5} \mathrm{mM}$ and $0.0080 \mathrm{mM}$ for soybean and horseradish peroxidase, respectively. Based on the curve (Fig. 5b, red line), it is clear that the mathematical model without dye inhibition does not correspond to the presented set of experimental values.

\section{Table 2}

Kinetic parameters attained by modeling with Ping-Pong Bi-Bi mechanism equations without hydrogen peroxide and with dye inhibition

\begin{tabular}{|c|c|c|c|c|}
\hline \multicolumn{5}{|c|}{$\mathrm{H}_{2} \mathrm{O}_{2}$ inhibition } \\
\hline$v_{\max }, \mathrm{mM} / \min$ & $K_{m}^{D y e}, \mathbf{m M}$ & $K_{m}^{H_{2} O_{2}}, M m$ & $K_{I}^{H_{2} o_{2}}, \mathrm{mM}$ & $R^{2}$ \\
\hline 15.7880 & 0.0246 & 0.1091 & I & 0.9981 \\
\hline \multicolumn{5}{|c|}{ Dye inhibition } \\
\hline$v_{\max }, \mathrm{mM} / \mathrm{min}$ & $K_{m}^{D y e}, \mathbf{m M}$ & $K_{m}^{H_{2} O_{2}}, \mathrm{mM}$ & $K_{I}^{D y e}, \mathrm{mM}$ & $R^{2}$ \\
\hline 14.3210 & 0.0052 & 0.0011 & $7.1234 \times 10^{-5}$ & 0.9203 \\
\hline
\end{tabular}

\section{CONCLUSION}

The crude peroxidase extract from soybean seeds exhibited promising results regarding the biodegradation of the Acid Violet 109 dye. The crude enzyme extract showed an activity of 25 $\mathrm{IU} / \mathrm{ml}$, which is exceptional when compared to crude peroxidase extracts from other plant materials, such as cabbage, tomato, turnip, and radish. The $81.88 \%$ biodegradation at $\mathrm{pH} 4$ in 30 min suggests that soybean peroxidase has the potential capacity for the treatment of colored effluents. The low demand of hydrogen peroxide contributes to a cleaner treatment process together with mild operation conditions. The following values of the parameters: $0.1 \mathrm{IU} / \mathrm{ml}$ enzyme activity, $1 \mathrm{mM}$ hydrogen peroxide and $40 \mathrm{mg} / \mathrm{l}$ dye concentration were shown to be optimal for dye biodegradation. The Michaelis constant for the dye is $0.0052 \mathrm{mM}$, which shows the strong affinity of the soybean peroxidase towards the dye. In regards to hydrogen peroxide, the results have shown that there is no inhibition present in the examined concentration range. Future work on biodegradation performances will include toxicity testing, convenient immobilization, continuous process, or a combination of both, as well as a broadened analysis of the process parameters in terms of the effects of individual ions that may be found in wastewaters.
Acknowledgment. This work was supported by the Ministry of Education, Science and Technological Development of the Republic of Serbia (Contracts No. 451-0368/2020-14/200287 and 451-03-68/2020-14/200135).

\section{REFERENCES}

[1] P. M. Vitousek, H. A. Mooney, J. Lubchenco, J. M. Melillo, Human domination of earth's ecosystems, Science, 277, 494-499 (1997).

DOI: $10.1126 /$ science. 277.5325 .494

[2] W. V. Reid, H. A. Mooney, A. Cropper, D. Capistrano, S. R. Carpenter, K. Chopra, P. Dasgupta, T. Dietz, A. K. Duraippah, Ecosystems and Human Well-being: Biodiversity Synthesis. A report of the Millennium Ecosystem Assessment, 2005.

https://www.millenniumassessment.org/documents/docu ment.356.aspx.pdf, accessed March 2020.

[3] M. Meybeck, Global analysis of river systems: From Earth system controls to Anthropocene syndromes, Philos. Trans. R. Soc. Lond B BiolSci., 29, 1935-1955 (2003). DOI: 10.1098/rstb.2003.1379

[4] FAO, The State of the World's Land and Water Resources for Food and Agriculture (SOLAW) - Managing Systems at Risk. Food and Agriculture Organization of the United Nations, Rome and Earthscan, London, 2011.

[5] A. Pandey, P. Singh, L. Iyengar, Bacterial decolorization and degradation of azo dyes, Int. Biodeter. Biodegr., 59, 73-84 (2007). DOI:10.1016/j.ibiod.2006.08.006

[6] M. A. Hassan, A. E. Nemr, Health and environmental impact of dyes: mini review, American J. Environ. Sci. Eng., 3, 64-67 (2017).

DOI: $10.11648 /$ j.ajese.20170103.11 
[7] R. Jamee, R. Siddique, Biodegradation of synthetic dyes of textile effluent by microorganisms: an environmentally and economically sustainable approach, Eur. $J$. Microbiol. Immunol., 9, 114-118 (2019). DOI: $10.1556 / 1886.2019 .00018$

[8] Q. Husain, M. Husain, Y. Kulshrestha, Remediation and treatment of organopollutants mediated by peroxidases: a review, Crit. Rev. Biotechnol., 29, 94-119 (2009). DOI: $10.1080 / 07388550802685306$

[9] R. S. Juang, F. C. Wu, R. L. Tseng, Characterization and use of activated carbons prepared from bagasses for liquid-phase adsorption, Colloids Surf. A, 201, 191-199 (2002). DOI: 10.1016/S0927-7757(01)01004-4

[10] N. K. Amin, Removal of reactive dye from aqueous solutions by adsorption onto activated carbons prepared from sugarcane bagasse pith, Desalination, 223, 152 161 (2008). DOI: 10.1016/j.desal.2007.01.203

[11] R. L. Tseng, F. C. Wu, R. S. Juang, Liquid-phase adsorption of dyes and phenols using pinewood-based activated carbons, Carbon, 41, 487-495 (2003). DOI: 10.1016/S0008-6223(02)00367-6

[12] S. B. Wang, Z. H. Zhua, A. Coomes, F. Haghseresht and G. Q. Lu, The physical and surface chemical characteristics of activated carbons and the adsorption of methylene blue from wastewater, J. Colloid Interface Sci., 284, 440-446 (2005).

DOI: $10.1016 /$ j.jcis.2004.10.050

[13] N. H. Phan, S. Rio, C. Faur, L. Le Coq, P. Le Cloirec and T. H. Nguyen, Production of fibrous activated carbons from natural cellulose (jute, coconut) fibers for water treatment applications, Carbon, 44, 2569-2577 (2006), DOI: 10.1016/j.carbon.2006.05.048

[14] S. Irudhaya Raj, A. Jaiswal, I. Uddin, Tunable porous silica nanoparticles as a universal dye adsorbent, RSC $A d v .$, 9, 11212 (2010). DOI: 10.1039/C8RA10428J

[15] X. Huang, S. Sun, B. Gao, Q.Yue, Y. Wang, Q. Li, Coagulation behavior and floc properties of compound bioflocculant-polyaluminum chloride dual-coagulants and polymeric aluminum in low temperature surface water treatment, J. Environ. Sci., 30, 215-222 (2015). DOI: $10.1016 /$ j.jes.2014.07.033

[16] S. S. Thakur, S. Choubey, Use of tannin based natural coagulants for water treatment: An alternative to inorganic chemicals, Int. J. ChemTech Res., 6, 36283634 (2014).

[17] A. Mishra, M. Bajpai, Flocculation behavior of model textile wastewater treated with a food grade polysaccharide, J. Hazard. Mater., 118, 213-217 (2015). DOI: 10.1016/j.jhazmat.2004.11.003

[18] E. M. Cuerda-Correa, M. F. Alexandre-Franco, C. Fernández-González, Advanced oxidation processes for the removal of antibiotics from water. An Overview. Water, 12, 102 (2020). DOI: 10.3390/w12010102

[19] M. E. Lovato, M. L. Fiasconaro, C. A. Martín, Degradation and toxicity depletion of RB19 anthraquinone dye in water by ozone-based technologies, Water Sci Technol., 75, 813-822 (2017). DOI: https://doi.org/10.2166/wst.2016.501

[20] S. Kliś, M. Thomas, K. Barbusiński, K. Gołombek, Ł. Krzemiński, M. Chyc, Removal of azo dye acid red 27 from aqueous solutions using classical and modified Fenton reagent with zero-valent iron, Fibre Text East Eur., 27, 100-106 (2019).

DOI: $10.5604 / 01.3001 .0013 .2908$

[21] H. Wang, J. Q. Su, X.W. Zheng, Bacterial decolorization and degradation of the reactive dye Reactive Red 180 by Citrobacter sp. CK3, Int Biodeterior Biodegrad., 63, 395-399 (2009). DOI: 10.1016/j.ibiod.2008.11.006

[22] J. Forss, M. V. Lindh, J. Pinhassi, U. Welander, Microbial biotreatment of actual textile wastewater in a continuous sequential rice husk biofilter and the microbial community involved, Plos One, 12, 0170562 (2017). DOI: 10.1371/journal.pone.0170562

[23] J. Wang, Y. Zhou, P. Li, H. Lu, R. Jin, G. Liu, Effects of redox mediators on anaerobic degradation of phenol by Shewanella sp. XB, Appl. Biochem. Biotechnol., 175, 3162-3172 (2015). DOI: 10.1007/s12010-015-1490-9

[24] S. Ren, J. Guo, G. Zeng, G. Sun. Decolorization of triphenylmethane, azo, and anthraquinone dyes by a newly isolated Aeromonas hydrophila strain, Appl. Microbiol. Biotechnol., 72, 1316-1321 (2006). DOI: $10.1007 / \mathrm{s} 00253-006-0418-2$

[25] X. H. Xie, N. Liu, B. Yang, Comparison of microbial community in hydrolysis acidification reactor depending on different structure dyes by Illumina MiSeq sequencing. Int. Biodeterior. Biodegrad. 111, 14-21 (2016). DOI: 10.1016/j.ibiod.2016.04.004

[26] M. M. Al-Ansari, B. Saha, S. Mazloum, K. E. Taylor, J. K. Bewtra, N. Biswas, Soybean peroxidase applications in wastewater treatment. In: Soybeans: Cultivation, Uses and Nutrition, Jason E. Maxwell (Ed.), Nova Science Publishers Inc., 2011, 189-221.

[27] S. Shen, Q. Wang, J. Shu, L. Ma, L. Chen, Y. Xu, Optimization of horseradish peroxidase catalytic degradation for 2-methyl-6-ethylaniline removal using response surface methodology, Water, 11, 1093 (2019). DOI: $10.3390 / w 11051093$

[28] R. Ahirwar, J. G. Sharma, B. Singh, K. Kumar, P. Nahar, S. Kumar, A simple and efficient method for removal of phenolic contaminants in wastewater using covalent immobilized horseradish peroxidase, J. Mat. Sci. Engin. B, 7, 27-38 (2017). DOI: 10.17265/2161-6221/2017.1-2.004

[29] M. Wagner, J. A. Nicell, Evaluation of horseradish peroxidase for the treatment of estrogenic alkylphenols, Water. Qual. Res. J. Canada, 40, 145-154 (2005). DOI: $10.2166 /$ wqrj.2005.017

[30] C. Ely, M. L. B. Magalhães, C. H. L. Soares, E. Skoronski, Optimization of phenol removal from biorefinery effluent using horseradish peroxidase, $J$. Environ. Eng., 143, 04017075 (2017). DOI: 10.1061/(ASCE)EE.1943-7870.0001279

[31] N. Šekuljica, N. Prlainović, S. Jakovetić, S. Grbavčić, N. Ognjanović, Z. Knežević-Jugović, D. Mijin, Removal of anthraquinone dye by cross-linked enzyme aggregates from fresh horseradish extract, Clean - Soil Air Water, 44, 891-900 (2016). DOI: 10.1002/clen.201500766

[32] A. G. Marangoni, E. D. Brown, D. W. Stanley, R. Y. Yada, Tomato Peroxidase: Rapid Isolation and Partial Characterization, J. Food. Sci., 54, 1269-1271 (1989). DOI:10.1111/j.1365-2621.1989.tb05971.x 
[33] A. A. Abbas, Extraction, Purification and characterization of peroxidase from cabbage (Brassica oleraceaVar), Iraqi. J. Sci., 56, 2282-2291 (2015).

[34] X. Zhang, X. Shao, Characterisation of Polyphenol Oxidase and Peroxidase and the Role in Browning of Loquat Fruit. Czech J. Food Sci. 33, 109-117 (2015). DOI: $10.17221 / 384 / 2014-C J F S$

[35] F. Ghaemmaghami, I. Alemzadeh, S. Motamed, Seed coat soybean peroxidase: extraction and biocatalytic properties determination, Iran. J. Chem. Eng., 7, 28-38 (2010).

[36] G. Hailu, A. Weersink, F. Cahlík, Examining the Prospects for Commercialization of Soybean Peroxidase, J. Agrobiotehcnol. Manag. Econom., 13, 263-273 (2010).

[37] J. A. Torres, F. G. E. Nogueira, M. C. Silva, J. H. Lopes, T. S. Tavares,T. C. Ramalhoa and A. D. Correa, Novel eco-friendly biocatalyst: soybean peroxidase immobilized onto activated carbon obtained from agricultural waste. $R S C A d v$. 7, 16460 (2017). DOI: $10.1039 / C 7 R A 01309 D$

[38] J. P. McEldoon, J. S. Dordick, Unusual thermal stability of soybean peroxidase. Biotechnol. Prog. 12, 555-558 (1996). DOI: 10.1021/bp960010x

[39] L. G. C. Villegas, D. Mukherjee, K. E. Taylor, N. Biswas, Enzymatic treatment with soybean peroxidase of an azodye, direct black 38, and an azo-dye precursor, 4- chloro-otoluidine. CSCE 2018 Annual Conference: Building Tomorrow's Society in Fredericton, Canada, 2018.

[40] H. Wright, J. A. Nicell, Characterization of soybean peroxidase for the treatment of aqueous phenols Bioresour. Technol., 70, 69-79 (1999). DOI: 10.1016/S0960-8524(99)00007-3

[41] L. Ali, R. Algaithi, H. M. Habib, U. Souka, M. A. Rauf, S. S. Ashraf, Soybean peroxidase-mediated degradation of an azo dye - a detailed mechanistic study. $B M C$ Biochem. 14, 35 (2013). DOI: 10.1186/1471-2091-14-35

[42] F. Alyas, M. Z. Anjum, K. Rehman, Extraction and purification from soybean seeds, Pak. J. Agri. Sci. 39, 326-329 (2002)

[43] S. Rathnamsamy, R. Singh, R. Auxilia, B. N. Vedhahari, Extraction of peroxidase from various plant sources and its biodegradation studies on phenolic compounds. Biotech. Ind. J. 9, 160-165 (2014).

[44] A. S. Mahmoud, A. E. Ghaly, S. L. Brooks, Influence of temperature and $\mathrm{pH}$ on the stability and colorimetric measurement of textile dyes, Am. J. of Biotechnol. Biochem., 3, 33-41 (2007).

DOI: 10.3844/ajbbsp.2007.33.41

[45] A. Kaur, K. E. Taylor, N. Biswas, Soybean peroxidasecatalyzed degradation of a sulfonated dye and its azoclavage product, J Chem. Technol. Biotechnol., 2020. DOI: $10.1002 /$ jctb.6555

[46] N. Šekuljica, N. Prlainović, A. Stevanović, M. Žuža, D. Čičkarić, D. Mijin, Z. Knežević-Jugović, Decolorization of anthraquinonic dyes from textile effluent using horseradish peroxidase: Optimization and kinetic study, Sci. World J., 37625 (2015). DOI: 10.1155/2015/371625

[47] E. M. Mandujano, G. M. Chavez, O. V. Rosas, G. Buitron, M. A. G. Zuniga, Decolourization of Direct blue 2 by peroxidases obtained from an industrial soybean waste, Water SA, 44, 204-210 (2018). DOI: $10.4314 /$ wsa.v44i2.06

[48] E. Routoula, S. V. Patwardhan, Degradation of anthraquinone dyes from effluents: a review focusing on enzymatic dye degradation with industrial potential. Environ. Sci. Technol., 54, 647-664 (2020). DOI: 10.1021/acs.est.9b03737

[49] M. C. Silva, J. A. Torres, L. R. Vasconcelos, P. M. B. Chagas, V. S. F. Leitao, A. D. Correa, The use of soybean peroxidase in the docolourization of Remazol brilliant blue $\mathrm{R}$ and toxicological evaluation of its degradation products, J. Mol. Catal. B Enzym., 89, 122 129 (2013). DOI: 10.1016/j.molcatb.2013.01.004

[50] L. G. C. Villegas, S. Mazloum, K. E Taylor, N. Biswas, Soybean peroxidase-catalyzed treatment of azo dyes with or without Feo pretreatment, Water Environ Res., 90, 675-684 (2018). DOI: 1 0.2175/106143017X15131012153149

[51] T. Chiong, S. Y. Lau, Z. H. Lek, B. Koh, M. K. Danquah, Enzymatic treatment of methyl orange dye in synthetic wastewater by plant-based peroxidase enzyme, J. Environ. Chem. Eng., 4, 2500-2509 (2016). DOI: 10.1016/J.JECE.2016.04.030

[52] C. Watanabe, A. Kashiwada, K. Matsuda, K. Yamada Soybean peroxidase-catalyzed treatment and removal of BPA and bisphenol derivatives from aqueous solution, Environ. Prog. Sustain. Energy, 30, 81-91 (2011). DOI: $10.1002 /$ ep.10453

[53] S. Longu, R. Medda, A. Padiglia, J. Z. Pedersen, G. Floris, The reaction mechanism of plant peroxidases, Ital. J. Biochem., 53, 42-46 (2004). 